\title{
PENGARUH INFORMASI \\ DALAM MEMBENTUK PERSEPSI \\ (Perspektif Al-Quran dan Hadits)
}

\author{
H. Harjani Hefni
}

\begin{abstract}
Abstrak
Al-Quran dan Hadits memberikan perhatian serius terhadap masalah informasi, karena informasi memainkan peranan penting dalam pembentukan persepsi masyarakat. Persepsi yang benar akan berpengaruh kepada sikap dan bahkan karakter manusia, dan persepsi yang salah akan berdampak pada penyikapan yang salah terhadap sesuatu. AlQuran dan Hadits memberikan arahan mana informasi yang boleh dipublikasi dan mana yang harus ditutup.
\end{abstract}

Kata Kunci : Tafsir, Informan, Kehidupan

\section{A. Pendahuluan}

Kita adalah apa yang kita dengar, apa yang kita lihat, dan apa yang kita pikirkan. Seperti apa kualitas kita sangat tergantung dengan apa yang sering kita dengar, apa yang kita lihat dan apa yang kita pikirkan. Objek yang kita dengar adalah informasi, objek yang kita lihat adalah informasi, dan apa yang kita pikirkan juga melahirkan informasi. Karena itu, informasi adalah kehidupan.

\section{B. Perangkat Penerima Informasi}

Sejak lahir seluruh perangkat untuk menyerap informasi seperti mata, telinga dan hati sebagai perangkat utama kehidupan sudah terpasang pada setiap manusia dan sudah siap difungsikan. Selain alat penangkap informasi, Allah juga sudah menyiapkan perangkat untuk menyampaikan kembali informasi yang telah ditangkap kepada orang lain. Alat itu adalah lidah, dua bibir dan segala hal yang terkait.

Di antara ayat yang menyatakan hal ini ialah firman Allah:

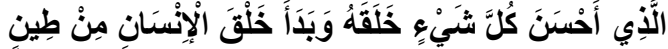

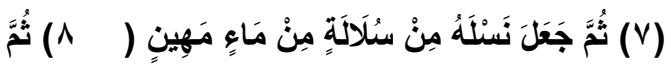

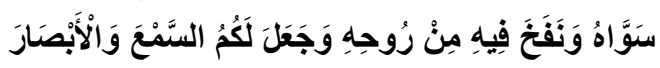

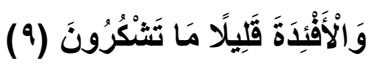


keturunannya dari saripati air yang hina. Kemudian Dia menyempurnakan dan meniupkan ke dalamnya roh (ciptaan)-Nya dan Dia menjadikan bagi kamu pendengaran, penglihatan dan hati; (tetapi) kamu sedikit sekali bersyukur." (QS. Al-Sajadah: 7-9).

Ketika menafsirkan pendengaran, penglihatan, dan hati, Imam al-Thabari mengatakan:

"...dan Dia menganugerahkan nikmat kepada kalian pendengaran yang dengannya kalian dapat mendengar suara, penglihatan yang dengannya kalian dapat melihat orang, serta hati yang dengannya kalian dapat membedakan mana yang baik dan buruk..."1

Imam al-Syaukâni dalam tafsirnya

Fath al-Qadîr menafsirkan fungsi ketiga perangkat itu lebih luas. Imam alSyaukâni mengatakan:

"...kalian dapat mendengar segala hal yang ditangkap dengan pendengaran, melihat segala objek yang bisa dilihat, mengikat segala hal yang bisa dipikirkan, dan memahami segala hal yang bisa dipahami..."2

Jika Imam al-Thabari menjelaskan fungsi pendengaran, penglihatan, dan hati dengan memberikan contoh, Imam

\footnotetext{
${ }^{1}$ Muhammad bin Jarir bin Yazid bin Katsir bin Ghalib alĂmili, Abu Ja'far al-Thabari, Jâmi' al-Bayân fî Ta'wîl al-Quran, (Mu'assasah al-Risalah, 1420-2000), juz 20, h.173, cet.1; Tafsir ayat 9 Surah al-Sajadah,.

${ }^{2}$ Muhammad bin Ali bin Muhammad bin Abdillah alSyaukâni al-Yamani, Fath al-Qadîr (Dimasyq: Dâr lbn Katsîr, 1414), jilid 4, h.288, Cet.1.
}

al-Syaukâni menjelaskan tentang fungsi tiga perangkat itu dengan fungsi umum.

Tidak lama setelah Adam diciptakan dengan dibekali tiga perangkat di atas, Allah swt mengajarkan kepada Adam semua nama benda sebagai bekal untuk menjadi khalifah di muka bumi. Dan ketika Adam sudah memiliki ilmu tentang nama-nama benda yang ada, Allah perintahkan kepadanya untuk menyampaikan dan menginformasikannya kepada para malaikat. Dengan kelebihan ilmu yang dianugerahkan kepadanya, Allah memerintahkan kepada para Malaikat untuk bersujud kepada Adam. ${ }^{3}$

Selanjutnya Allah menciptakan Hawwa sebagai pasangan hidup dan teman berbagi rasa dan informasi. Hadirnya Hawwa membawa kedamaian bagi Adam 'alaihissalam, dan dari keduanya lahir keturunan laki-laki dan perempuan yang banyak. ${ }^{4}$

Kisah manusia pertama di muka bumi di atas mengajarkan kepada kita bahwa manusia sejak lahir memiliki sifat penasaran ingin mengetahui sesuatu yang ada di sekitarnya. Rasa penasaran

\footnotetext{
3 Lihat, al-Quran dan Terjemahnya, ( Al-Madinah alMunawwarah: Majma' Khâdim al-Haramain alSyarîfain al-Malik Fahd li-Thibâ-'at al-Mudhad alSyarîf, $1411 \mathrm{H}$ ), Surah al-Baqarah: 31-34.

${ }^{4}$ Lihat, al-Quran dan Terjemahnya, ( Al-Madinah alMunawwarah: Majma' Khâdim al-Haramain alSyarîfain al-Malik Fahd li-Thibâ-'at al-Mudhad alSyarîf, 1411 H), Surah al-Nisâ': 1.
} 
dan haus ingin mengetahui sesuatu merupakan faktor utama yang menyebabkan komunikasi berlangsung. Rasa haus untuk mengetahui sesuatu itulah yang menyebabkan anak kecil selalu bertanya dengan orang tuanya tentang obyek yang ada di sekitarnya. Untuk memenuhi kebutuhan ingin tahu tentang alam di sekitarnya itu, Allah ajarkan kepada Adam seluruh nama dan istilah di alam ini.

Setelah memiliki ilmu dan pengalaman, manusia biasanya tidak betah memendam ilmu dan pengalaman di dalam dirinya sendiri. Biasanya muncul keinginan untuk berbagi ilmu dan pengalaman dengan teman-temannya. Kebutuhan untuk berbagi ilmu dan pengalaman itu Allah salurkan lewat perintah-Nya kepada Adam untuk mengajarkan ilmu yang telah dia miliki kepada para malaikat.

Selain makhluk yang haus ilmu, manusia diciptakan sebagai makhluk yang memiliki perasaan. Manusia juga tidak mampu untuk hidup dengan memendam perasaan. Karenanya, Allah ciptakan untuk Adam pasangan hidup yang bernama Hawwa. Keberadaan teman apalagi pasangan hidup membuat Adam bebas dan lepas menumpahkan perasaannya.

Kisah di atas juga mengajarkan bahwa orang yang akan menjadi pemimpin harus memiliki banyak informasi, dan orang yang unggul dalam informasi akan dimuliakan. Karena Adam memiliki informasi yang tidak dimiliki oleh malaikat, maka Allah memerintahkan malaikat untuk sujud kepada Adam.

Ketika komunikasi terjadi, maka tukar menukar informasi tidak bisa dihindarkan. Informasi adalah kunci utama terjadinya perubahan sikap dan perilaku pada manusia. Seseorang yang memiliki informasi kurang baik tentang si fulan secara umum akan bersikap negative tentang orang tersebut. Tetapi jika informasi yang masuk tentang si fulan tersebut positif, maka kemungkinan besar sikap orang terhadap si fulan itu juga akan baik.

\section{Pengaruh Informasi Dalam Kehidupan: Pelajaran dari Kisah 'Aisyah}

Kisah Aisyah di bawah ini mengandung banyak pelajaran terkait dengan besarnya pengaruh informasi dalam membentuk persepsi seseorang terhadap sesuatu. Semua peristiwa itu terjadi setelah kaum muslimin - dengan membawa tawanan dan rampasan perang- kembali ke Madinah. Namun kemudian ada suatu peristiwa yang pada mulanya tidak memberi dampak apa pun, tiba-tiba menjadi masalah besar; peristiwa 
yang terkait dengan Ummul Mukminin Aisyah.

Biasanya, bila Nabi SAW bepergian, Beliau mengadakan undian terhadap istri-istrinya. Barangsiapa yang keluar namanya, maka dialah yang ikut serta.

Sorenya, menjelang keberangkatan ke Bani Mushtaliq akan dilakukan, yang keluar namanya adalah Aisyah. Jadi Aisyahlah yang dibawa oleh Rasulullah saw saat itu. Aisyah adalah seorang wanita yang berperawakan kecil dan ringan. Ketika pelangkin (semacam tandu) sudah diantarkan orang sampai di depan pintu tendanya, Aisyahpun naik. Lalu mereka membawanya ke punggung unta. Saking ringannya, mereka hampir tidak dapat merasakan keberadaan Aisyah dalam pelangkin.

Selesai dari peperangan Bani Musthaliq itu, Nabi dan rombongannya berangkat lagi meneruskan perjalanan yang panjang dan sangat melelahkan. Sesudah itu beliau menuju Madinah. Menjelang masuk kota, Rasulullah berhenti dan bermalam di sana. Setelah istirahat cukup, maka diumumkan kepada rombongan bahwa perjalanan akan diteruskan lagi.

Karena hendak menunaikan hajat, Aisyah keluar dari kemah Nabi, sedang pelangkin sudah menunggu di depan tenda, menantikan ia masuk kembali. Aisyah mengenakan seuntai kalung, dan setelah menyelesaikan keperluannya, Aisyah baru tersadar, ternyata kalung yang dia kenakan telah lepas dari lehernya. la pun kembali menyusuri jalan sambil mencari-cari kalung yang terjatuh. Dan setelah sekian lama mencari, Aisyah menemukan kembali kalung tersebut. Setelah itu Aisyah langsung menuju pelangkin. Ternyata rombongan semua sudah berangkat, karena mereka mengira bahwa Ummul Mukminin sudah berada di dalamnya.

Ketika tiba di lokasi peristirahatan, Aisyah tidak menemukan seorang pun di tempat itu.Meskipun demikian, Aisyah tidak panik, tidak merasa takut atau khawatir dengan kejadian itu. Dia yakin rombongan itu akan menyusulnya kembali jika mengetahui ternyata ia tidak ada di punggung unta. Dengan asumsi seperti itu, Aisyah memutuskan untuk tidak meninggalkan tempat daripada mengarungi padang pasir tanpa pedoman. Aisyah pun berbaring di situ dengan berselimutkan pakaian luarnya, sambil menunggu orang yang akan datang mencarinya.

Pada saat sedang berbaring itu, Shafwan bin Mu'athal lewat di tempat tersebut. Shafwan juga terlambat ikut rombongan pasukan karena harus menunaikan urusannya pula. Shafwan sebelumnya pernah melihat Ummul Mukminin Aisyah, sebelum ada 
ketentuan hijab terhadap istri-istri Nabi. Begitu melihat Aisyah, Shafwan sangat terkejut dan melangkah mundur sambil berkata, "Inna lillahi wa inna ilaihi raji'un! Istri Rasulullah SAW! Kenapa anda sampai tertinggal?" ujarnya.

Aisyah tidak menjawab pertanyaan itu. Shafwan mendekatkan untanya dan dia sendiri mundur sambil berkata, "Naiklah, wahai Ummul Mukminin!"

Setelah Aisyah naik, Shafwan kemudian segera memacu untanya lebih cepat supaya bisa menyusul rombongan yang lain. Ternyata usaha itu tidak membuahkan hasil, karena rombongan ternyata mempercepat perjalanan agar segera sampai di Madinah. Pasukan Muslimin ingin segera dapat beristirahat setelah mengalami perjalanan yang sangat melelahkan, perjalanan yang juga diperintahkan oleh Rasulullah guna menghindarkan fitnah yang hampirhampir terjadi akibat perbuatan Abdullah bin Ubay.

Shafwan memasuki Madinah pada siang hari disaksikan orang banyak, sementara Aisyah di atas untanya. Sampai di depan rumahnya, Aisyahpun masuk. Tak terlintas dalam pikiran orang bahwa peristiwa ini akan dijadikan buah bibir, atau akan menimbulkan fitnah. Dalam hati Rasulullah sendiri tidak terlintas suatu prasangka buruk terhadap
Shafwan, sosok pribadi Mukmin yang beriman teguh.

Juwairiyah binti Harits termasuk salah seorang tawanan perang Bani Mushtaliq. Dia seorang wanita cantik dan manis. la menjadi bagian salah seorang Anshar. Dalam hal ini ia ingin menebus diri.Karena itu, ia segera pergi menemui Nabi yang saat itu sedang berada di rumah Aisyah.

"Saya Juwairiyah putri Harith bin Abi Dzirar, pemimpin masyarakat," katanya. "Saya mengalami bencana, seperti sudah tuan ketahui tentunya. Tetapi karena saya sudah menjadi milik si fulan, maka saya telah mengajukan penawaran untuk membebaskan diri saya. Kedatangan saya kemari ingin mendapat bantuan tuan mengenai penawaran itu." "Maukah engkau dengan yang lebih baik dari itu?" tanya Nabi SAW. "Apa?" "Saya penuhi penawaranmu dan saya menikahimu," kata Rasulullah. Setelah berita itu tersiar, sebagai penghormatan terhadap ikatan kekeluargaan Rasulullah dengan Bani Mushtaliq, tawanan-tawanan perang yang ada di tangan pasukan Muslimin segera dibebaskan. Sehingga mengenai Juwairiyah ini, Aisyah pernah berkata, "Tak pernah saya lihat ada seorang wanita yang lebih besar membawa keuntungan buat golongannya seperti dia ini." 
Setelah Rasulullah menikah dengan Juwairiyah, beliau membuatkan rumah untuknya di samping rumah-rumah istrinya yang lain di dekat mesjid. Dengan demikian, Juwairiyah pun menjadi Ummul Mukminin pula.

Sementara itu, orang di luar mulai pula berbisik-bisik tentang keterlambatan Aisyah dan kedatangannya bersama Shafwan dengan menumpang untanya, sedang Shafwan sendiri seorang pemuda yang tegap dan tampan.

Saudara perempuan Zainab binti Jahsy yang bernama Hamnah, sudah tahu bahwa posisi Aisyah di hati Rasulullah lebih tinggi dibanding saudaranya itu. la segera menyebarkan desas-desus tentang Aisyah ini.

Dengan demikian, Abdullah bin Ubay merasa mendapat lahan subur dalam usahanya menyebarkan isu tersebut, yang sekaligus merupakan penawar terhadap api kebencian di hatinya. la mati-matian menyebarluaskan gosip ini. Namun dalam hal ini, kalangan Aus telah menentukan sikap untuk membela Aisyah. Ummul Mukminin Aisyah adalah lambang kesucian dan seorang wanita yang berakhlak tinggi, yang patut menjadi teladan. Peristiwa ini hampir saja menjadi fitnah besar di Madinah.

Berita-berita ini kemudian sampai juga kepada Rasulullah SAW. Tentu saja beliau resah dan gelisah. Beliau juga kebingungan, antara percaya atau tidak.

Orang-orang tidak ada yang berani menyampaikan desas-desus itu kepada Aisyah, meskipun ia sendiri sudah merasa aneh melihat sikap Rasulullah yang kaku terhadapnya. Suatu sikap yang belum pernah dilihatnya dan memang tidak sesuai dengan perangainya yang selalu lemah-lembut, selalu penuh kasih kepadanya.

Kemudian Aisyah jatuh sakit, dan sakitnya cukup parah. Bila Rasulullah datang menengoknya dan ibunya ada di tempat itu merawatnya, beliau hanya berkata, "Bagaimana?"

Aisyah merasa pilu melihat sikap Nabi yang begitu kaku kepadanya. Sehingga berkata, "Kalau kau izinkan, aku akan pindah ke rumah ibu, supaya ia dapat merawatku."

la pun pindah ke tempat ibunya. Sikap Rasulullah yang demikian menimbulkan kepedihan di hati Aisyah. Setelah lebih dari dua puluh hari menderita sakit, akhirnya Aisyah sembuh. Segala pembicaraan orang yang terjadi tentang dirinya, tidak ia ketahui.

Sebaliknya Rasulullah merasa sangat terganggu dengan berita-berita yang disebarkan orang-orang. Beliau kemudian berbicara di hadapan mereka. "Saudara-saudara, kenapa orang-orang menggangguku mengenai keluargaku. 
Mereka mengatakan hal-hal yang tidak sebenarnya mengenai diriku. Padahal yang kuketahui mereka itu orang baikbaik. Lalu mereka mengatakan sesuatu yang ditujukan kepada seseorang, yang kuketahui, demi Allah, dia juga orang baik. la tak pernah datang ke salah satu rumahku kecuali bersama denganku. "Kemudian Usaid bin Hudzair berdiri seraya berkata, "Wahai Rasulullah, kalau mereka itu adalah saudara-saudara kami dari kalangan Aus, biarlah kami selesaikan. Dan kalau mereka itu adalah saudara-saudara kami dari golongan Khazraj, perintahkanlah juga kepada kami. Sungguh patut leher mereka itu dipenggal." Kaum Khazraj tentu saja menolak, bahkan balik menuding Aus. Keadaan pun jadi ramai. Dan hampirhampir terjadi fitnah besar, jika Rasulullah tidak segera campur tangan dan menengahi mereka dengan kebijaksanaan beliau. $^{5}$

Cerita di atas menggambarkan besarnya peran informasi dalam membentuk persepsi seseorang dan mempengaruhi sikap mereka terhadap orang yang diberitakan. Orang sekelas Nabi Muhammad saja merasa terganggu dengan informasi yang beredar, bahkan berdampak pada perubahan sikap

\footnotetext{
${ }^{5}$ Kisah ini diriwayatkan oleh Imam Bukhari dalam Kitab Shahihnya, (Dōr Thũq al-Najōh, 1422) , Juz 5, h. 116, hadits no.4141.
}

terhadap istrinya. Ketika melihat Nabi merasa terusik dengan berita itu, masyarakat di bawah yang tidak rela keluarga Nabi diperlakukan seperti itu mulai bereaksi, bahkan hampir saja terjadi bentrok antar kabilah, karena muncul saling curiga di antara mereka tentang kelompok mana yang melancarkan fitnah terhadap keluarga Nabi.

\section{Dari Informasi ke Persepsi}

Dalam pandangan Islam, informasi adalah pintu awal seseorang memiliki persepsi tertentu, baik atau buruk. Bahkan dari informasi tersebut akan berujung kepada karakter. Ibnu Qayyim mengatakan bahwa karakter tidak terbentuk otomatis, tetapi melalui tahapan-tahapan. Pembentukan karakter dimulai dengan langkah mengumpulkan informasi tentang makna pesan (khawâthir dan afkâr), lalu terbentuk persepsi (tashawwur), lalu muncul keinginan (irâdah) dan akhirnya melahirkan perbuatan (fi'). Perbuatan yang dilakukan secara berulang akan melahirkan karakter ('adat). Baik tidaknya suatu karakter tergantung dari input informasi yang masuk. ${ }^{6}$

Mengingat pentingnya informasi dalam kehidupan manusia, maka Islam

\footnotetext{
${ }^{6}$ Ibnu al-Qayyim al-Jauziyyah, al-Fawa-id, (Beirut: Dâr al-Kutub al-'Ilmiyyah, 1393-1973),h.173.
} 
melarang keras umatnya untuk berdusta, karena dusta akan menciptakan fasâd altashawwur (rusaknya persepsi) seseorang terhadap orang lain atau terhadap sesuatu dan menyeret pelakunya untuk masuk neraka. ${ }^{7}$

Prinsip dasar agama Islam dalam menyebarkan informasi adalah menutup rapat informasi yang tidak baik yang terkait dengan orang lain, terutama yang terkait dengan masalah pribadi. Islam melarang namîmah atau mengungkap kejelekan orang lain, dan mengategorikan perbuatan ini sebagai salah satu dosa besar. ${ }^{8}$ Islam melarang orang yang bermimpi jahat untuk menyampaikan isi mimpinya kepada orang lain. ${ }^{9}$ Bahkan

\footnotetext{
${ }^{7}$ Rasulullah SAW bersabda:

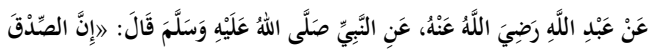

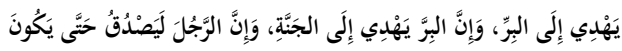

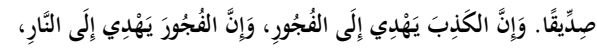

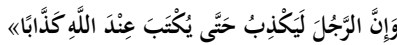

Sesungguhnya kejujuran itu memandu kepada kebaikan, dan kebaikan akan memandu orang ke surga. Sesungguhnya orang yang selalu jujur akan menjadi ahli jujur. Sedangkan dusta memandu orang kepada kejahatan, dan kejahatan memandu orang ke neraka. Sesungguhnya orang yang selalu berdusta akan ditetapkan menjadi ahli dusta." (Shahih Bukhari, juz 8, h.25, hadits no. 6094; Shahih Muslim, juz 4, h.2012, hadits no.103)

${ }^{8} \mathrm{Abu}$ Abdillah Muhammad bin Ahmad al-Dzahabi, alKabâ-ir, (Beirut: Dâr Ihyâ' al-'Ulûm, 1410-1990), h.268-273. Dari tujuh puluh dosa yang dimasukkan oleh Al-Dzahabi dalam kelompok dosa besar, namîmah dimasukkan dalam urutan ke-43.

${ }^{9}$ Dalam sebuah hadits yang diriwayatkan oleh Imam Muslim disebutkan:

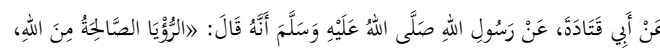

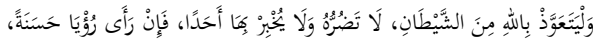

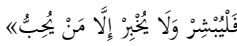

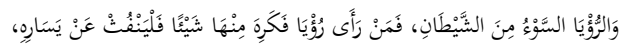

orang yang bangga menyampaikan informasi tentang kejahatan yang dia lakukan termasuk orang yang tidak diampuni dosanya oleh Allah. ${ }^{10}$

Pemberitaan korupsi yang sangat massif, kisah perceraian, pembunuhan, demonstrasi, perampokan, dan sejenisnya tanpa diimbangi dengan berita tentang prestasi, kejujuran, kasih sayang, dan kerja keras, akan melahirkan frustasi dan berita miring tentang bangsa ini.

Penulis lebih setuju jika kebaikan dan prestasi mendapatkan porsi utama dalam pemberitaan di media kita.

Mimpi yang baik bersumber dari Allah, dan mimpi buruk bersumber dari syetan. Barangsiapa melihat dalam mimpinya sesuatu yang tidak dia sukai, maka hendaklah dia meniupkan angin dari mulutnya ke bagian sebelah kirinya, dan hendaklah meminta perlindungan dari syetan, niscaya mimpi (buruk) itu tidak akan mempengaruhinya, dan janganlah dia memberitahukannya kepada siapapun. Jika dia melihat yang baik, maka bergembiralah dan jangan sampaikan kecuali kepada orang yang dia cintai. (HR. Muslim, Beirut: Dar Ihya' al-Turats al-'Arabi, t.th),juz 4, h.1772, hadits no. 2261.

${ }^{10}$ Dalam hadits shahih al-Bukhari diriwayatkan:

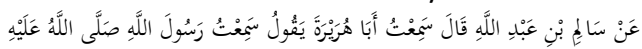

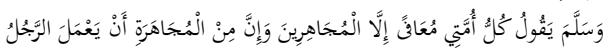

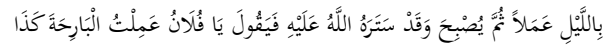

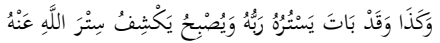

'Dari Salim bin Abdullah berkata, Aku mendengar Abu Hurairah berkata: Aku mendengar Rasulullah saw bersabda: "Semua umatku akan diampuni kecuali 'mujâhirîn'. Di Antara bentuk mujâharah ialah: seseorang melakukan perbuatan maksiat di malam hari, kemudian di pagi harinya ia menceritakan dengan bangga apa yang dia lakukan di malam harinya. Padahal Allah telah menutupinya, tapi dia sendiri membuka aib dirinya yang telah ditutup oleh Allah." (Imam al-Bukhari, Shahih Bukhari, (Dōr Thũq al-Najōh, 1422), Juz 8, h. 20, hadits no.6069. 


\section{E. Penutup}

Besarnya pengaruh informasi dalam membentuk persepsi manusia mengharuskan praktisi yang bergerak dalam jasa informasi agar selektif menyajikan informasi yang bermanfaat bagi masyarakat, sehingga terwujud masyarakat yang harmonis dan berkualitas.

\section{F. Daftar Pustaka}

Abu Abdillah Muhammad bin Ahmad al-Dzahabi, al-Kabâ-ir, (Beirut: Dâr Ihyâ' al-'Ulûm, 1410-1990).

Al-Quran dan Terjemahnya, AlMadinah al-Munawwarah: Majma' Khâdim al-Haramain alSyarîfain al-Malik Fahd li-Thibâ'at al-Mudhad al-Syarîf, $1411 \mathrm{H}$ ). Ibnu al-Qayyim al-Jauziyyah, al-Fawaid, (Beirut: Dâr al-Kutub al'Ilmiyyah), 1393-1973

Imam Bukhari, Shahih al-Bukhari, (Dar Thũq al-Najah, 1422)

Imam Muslim, Shahih Muslim, (Beirut:

Dar Ihya' al-Turats al-'Arabi), t.th. Muhammad bin Ali bin Muhammad bin Abdillah al-Syaukâni al-Yamani, Fath al-Qadîr (Dimasyq: Dâr Ibn Katsîr, 1414), Cet.1.

Muhammad bin Jarir bin Yazid bin Katsir bin Ghalib al-Ămili, Abu Ja'far al-Thabari, Jâmi' al-Bayân fî Ta'wîl al-Quran, (Mu'assasah al-Risalah, 1420-2000) 